\title{
Irakurtzeko gaitasuna Haur Hezkuntzan. Teoriatik praktikara
}

\author{
Ainara Romero Andonegui \\ ainara.romero@ehu.eus \\ Eneko Tejada Garitano \\ eneko.tejada@ehu.eus
}

Didaktika eta Eskola Antolakuntza

Bilboko Irakasleen Unibertsitate Eskola

Euskal Herriko Unibertsitatea UPV/EHU

Urtza Garay Ruiz

Hizkuntzaren eta Literaturaren Didaktika

Bilboko Irakasleen Unibertsitate Eskola

Euskal Herriko Unibertsitatea UPV/EHU

urtza.garay@ehu.eus

DOI: http://dx.doi.org/10.1387/tantak.17708

GAKO-HITZAK: Haur Hezkuntza, irakurketarako prestasuna, irakurtzeko gaitasuna, gaitasunen garapena, pedagogi praktika.

\section{IRAKURTZEKO GAITASUNA}

Gaur egungo gizartean irakurle trebea ez da soilik idatzitako hizkuntza modu egokian eta abiaduraz deskodetu eta ulertzen duena. Egungo irakurleak funtzio berriak egiteko erabili behar du idatzitako testua, hala nola ikasteko, entretenitzeko edota informazioa bilatzeko (Clemente eta Rodríguez, 2014). Irakurketa eredu horrek garapen maila altuagoa exijitzen du, irakurtzeko gaitasuna izatea hain zuzen.

Hezkuntza esparruan aspaldi ari gara Irakurtzeko Gaitasun kontzeptuaz hitz egiten. Izan ere, PISA 2009 Irakurketa Markoak honela definitzen du irakurtzeko gaitasuna: «(...) helburu pertsonalak erdiesteko, norberaren aukerak eta ezagutzak garatzeko, eta gizartean parte hartzeko xedeekin, irakurleak testu idatziak ulertzeko, erabiltzeko, haietaz gogoeta egiteko eta haiekin konprometitzeko duen gaitasuna da» (OECD, 2009b). Irakurtzeko 
gaitasun kontzeptu horrek ezagutzak, jarrerak eta estrategiak (kognitiboak, linguistikoak, pragmatikoak...) biltzen ditu; eta horiek guztiek erabileraren bidez hartzen dute zentzua, askotariko egoeretan aplikatuz eta helburu ezberdinei erantzunez (Berritzegune Nagusia, 2013).

Ildo honi jarraituz, lehen hezkuntzan eta bigarren hezkuntzan irakurtzeko gaitasunaren garapena bideratzeko ekimenak eta jarduerak planifikatzen eta bideratzen dira eta Heziberri 2020an irizpideak ere ematen dira Haur Hezkuntzako etapan irakurtzeko gaitasuna garatzen hasteko.

Izan ere, Haur hezkuntzan irakurtzeko gaitasuna garatzeko ildoak esplizituki zehazteak, pauso handia da gaindituta dauden teoriak praktikatik urruntzeko eta ikerketa berrien ondorioei bide emateko. Batez ere, horrek heltze-ereduek defendatzen duten «irakurketa heldutasuna» kontzeptua ar-

NORTASUNAREN ERAIKUNTZARENETA KOMUNIKAZIOAREN ETA ADIERAZPENAREN EREMUA

Haurrar en eskolak komunikaziorako esparru bat izan behar du, topaleku bat, eta esparru horr ek adiera aberatseko hizkuntza-eredu bat eskaini behar die haurrei, argia eta ongi egituratua. Eredu horrek, batik bat, komunikazioaukera askotarikoak eman behar dizkie haurrei, bai hezitzaileekin komunikatzeko, bai ikasgelako kideekin komunikatzeko, haien hip otesiak probatu eta kontrasta ditzaten.

Haurrar en hurbileko ingurunearen beste elementu bat da idazketa. Deigarri egiten zaie idazketa haurrei, eta idazteko gogoa pizten zaie, helduek egiten duten moduan jarduteko. Tkasgelan irakurketa eta idazketa modu a dierazkor eta fintzionalean erabiltzen baldin bada, haurrek, hezitzaileen laguntzar ekin, idazteko sistemar en ezaugarri eta arau batzuk ikasten hasiko dira, eta Lehen Hezkuntzako lehen zikloan osatuko dute idazketaren alorrean hasitako eskuratze-prozesu hori.

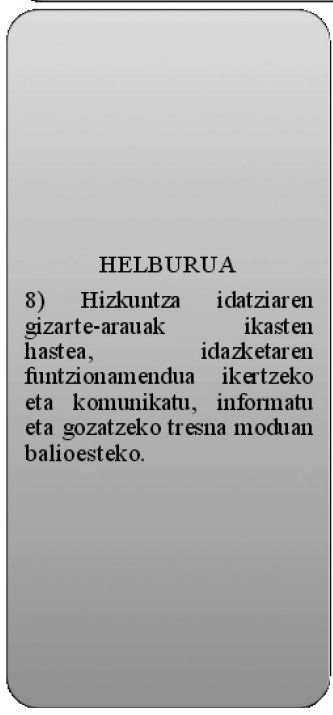

EDUKLAK

- Idatzizko hizkuntzara hurbiltzea, komunikatzeko, informatzeko eta gozatzeko bitartekoizan dakien.

- Testu idatzien ondoan dauden irudiak eskuez erabiltzea eta interpretatzea, eta irudien eta testuaren arteko loturak egitea

- Idatziak eta adierazpen grafikoari dagozkion bestelako adierazpenformak (marrazkiak, irudiak, zenbakiak, etab.) ber eiztea.

- Idazte-sistemaren arauak erabiltzen hastea.

- Hitz idatzien arteko difer entziak eta antzekotasunak hautematea.

- Testu irakurgarriak egiteko interesa izatea, eta arian-arian, hizkuntza idatziaren arauak betetzeko bidea urratzea.

- Gero eta autonomia handiagoz erabiltzea hizkuntza idatziar en euskarri a skotarikoak; hala nola, liburuak, aldizkariak, egunkariak, ordenagailuak, kartelak eta etiketak

- Liburutegia erabiltzen hastea eta hura informatzeko, ikasteko, entr etenitzeko eta gozatzeko baliabidea dela balioestea.

- Literatura-testu errazak, tradizionalak eta garaikoak, entzutea, ulertzea eta err ezitatzea, plazera sentitzeko eta ikasteko.

- Literatura-testu errazak dramatizatzen parte hartzea.

\section{Heziberri 2020an irakurtzeko gaitasunari buruz ematen diren Haur Hezkuntzarako irizpideak}


gitzea bideratzen du. Hau da, heltze-ereduen arabera, irakurtzea gaitasun pertzeptibo-bisuala da, hori dela eta haurrak irakurtzen hasi aurretik, heldutasun maila bat eta elementu psikomotor batzuk garatuta izan behar ditu (motrizitatea, orientazio espaziala, erritmoa, lateralitatea, gorputz-eskema, begi-eskuen koordinazioa...) (Jiménez eta Artiles, 1990). Baina heltze-ereduen argudioak ezeztatuta gelditu dira, gaitasun pertzeptibo-bisual bikainak izanik, irakurketa zailtasunak dituzten pertsonak badaudelako, eta alderantziz (Alegría, 2006). Hortaz, irakurtzeko zailtasunak dituzten haurren kasuan, hautemate-jardueretan oinarritzen diren esku-hartzeek ez dute eraginik izan irakurketa errendimenduan (Suárez-Coalla eta Cuetos-Vega, 2012).

Beraz, Heziberri 2020an irakurtzeko gaitasuna Haur Hezkuntzan txertatzeak bide ematen du irakurketaren garapena bideratzeko egun ditugun teorien ikuspegietatik, batik bat, ikuspegi psikolinguistikotik eta soziokulturaletik. Ikuspegi horiek aintzat hartuta, gaurko hezkuntza-esparruan, irakurtzeko gaitasunaren garapena oinarritzen da Haur Hezkuntzan irakurketaren aldeko jarreran eta irakurketaren dekodetzearen lehen hurbilketa burutzean (ikus 1. irudia).

Hala ere, hurbilketa garrantzitsua izanik, ikuspegi psikolinguistikotik eginiko ekarpen nagusienak falta dira; batez ere, irakurketaren eragileen gaineko ikerketaren ondorioak praktikara zelan eraman daitezkeen gidatzea edo aholkatzea. Irakurketaren eragileak edo irakurketaren aurrebaldintzak irakurtzen ikasteko aurretik garatu behar diren abileziak dira. Berebiziko garrantzia dute Haur Hezkuntzan, batetik, irakurtzen ikasteko prestutasunaren adierazleak direlako, eta bestetik, irakurketaren inguruko arrakasta iragartzeko edo aurresateko gakoak ematen dituztelako.

Hori guztia horrela izanik, artikulu honetan irakurtzeko gaitasuna Haur Hezkuntzan garatzeko landu beharreko aldagai psikolinguistikoak eta soziokulturalak zehaztuko dira eta horiek praktikara eramateko proposamenak bideratu.

\section{IRAKURTZEKO GAITASUNA GARATZEKO ALDAGAI ERRAZTAILEAK}

Hizkuntza idatziaren garapena ahalbideratzen dituzten aldagaiak ikuspegi integratzaile batetik aztertzeko, irakurketaren ikaskuntza-irakaskuntza azaltzen duten korronte nagusi biak aintzat hartu behar dira; ikuspegi soziokulturala eta psikolinguistika.

\section{Ikuspegi soziokulturala}

Ikuspegi honetan kokatzen diren autoreek baieztatzen dute irakurtzeko gaitasunaren garapenean interakzio sozialak (Bruner, 1991; Vygotsky, 
1979) eta ingurune kulturalak zein sozioekonomikoak (Snow, Burns eta Griffin, 1998) eragiten dutela.

Korronte honen ekarpen nagusia da irakurketa-idazketaren garapena etxean hasten dela eta familiak eragin zuzena duela haurraren alfabetatze prozesuan.

Familia-interakzio horretan gehien aztertu den gaia ipuin-kontaketak etorkizuneko irakurketaren garapenean duen inplikazioa izan da. Horrela, autore ezberdinek (Reese, Cox, Harte eta McAnally, 2003; Teale, 1984) frogatu dute ipuinak kontatzea etorkizuneko irakurketa arrakastaren aurresale ona dela. Baita ipuinen kalitateak eta kantitateak, haurraren hiztegiaren garapenean, irakurketa-idazketarekiko interesean, eta irakurketa-idazketa garatzeko erraztasunean eragiten duela (Sulzby eta Teale, 1991).

Hala ere, etxean egiten diren beste jarduera batzuek ahozkoaren eta idatzitakoaren kontzientzia bereganatzeko aukera ematen diezaiekete haurrei, hala nola liburuak eskaintzea, gurasoekin liburutegira joatea eta gurasoen irakurzaletasuna (Wasik, 2012).

Ikuspegi soziokulturaletik aztertu den beste gaietako bat izan da ingurune kulturalak zein sozioekonomikoak irakurketa garapenean duten eragina. Horretarako, maila sozioekonomiko ezberdinen familia-interakzioak eta narrazio momentuak aztertu dira. Ikerketa horietatik ondorioztatzen da ingurune kaltetuetan interakzio urriagoak ematen direla eta horien bitartekaritza maila baxuagoa dela (Korat, Klein eta Segal-Drori, 2007). Horrek guztiak maila sozioekonomiko baxuko haurren irakurketa garapenaren arrakastari eragiten dio, ematen diren interakzio urriek alfabetatze lasterraren hiru abilezia nagusien garapena atzeratzea eragiten dutelako; ahozko hizkuntza, ezagutza alfabetikoa eta prozesatze fonologikoa (Beltrán et al., 2006; Snowling, 2013). Hala ere, kontutan hartu behar da maila sozioekonomiko eta kultural desberdineko haurrek islatzen dituzten aldeen arrazoiak askotarikoak eta konplexuak izan daitezkeela (Snowling, 2013). Alde batetik, ingurune kaltetuetan dauden baliabideak kontuan hartu behar dira, eta bestetik, gurasoek alfabetatze jarduerei buruz dituzten usteak zein baloreak (Harris, 2003) beren seme-alaben alfabetatzean eragiten dutela.

Beraz, argi dago maila sozioekonomikoak zein kulturalak haurren alfabetatze lasterrean ezberdintasunak eragiten dituela baina sarritan ingurune kaltetuetan ematen diren kontrako ondorioak beste senideen, komunitateen edota indar kulturalen eraginagatik gutxitu edo leundu daitezke. Esparru horretan, eskolak eta bereziki Haur Hezkuntzako etapak zerikusi zuzena izan dezake, irakaskuntza sistematikoak alfabetatze trebetasunaren gaineko etxeko gabezia bete dezakeelako (Lonigan, 2004).

Ondorioz, korronte soziokulturalaren arabera, irakurketa egintza sozialetik eraiki behar da, haurrari irakurketan parte hartzeko aukerak eskainiz eta irakurketan esku-hartzeko modalitate ezberdinak erakutsiz. Partaidetza funtsezkoa izango da irakurketaren aniztasuna ezagutzeko eta irakurketak gizartean dituen funtzioak bereizteko. 
Baina irakurketa garatzeko aurreko guztia kontuan hartu beharrekoa bada ere, irakurtzea ez da naturalki gauzatzen den zerbait (Dehaene, 2009), beraz, irakurle bilakatzeko irakurketa kodea ikasi eta automatizatu behar da eta ildo horretatik psikolinguistikaren zientziak eskaini ditu ekarpen nagusiak.

\section{Ikuspegi psikolinguistikoa}

Zientziaren eta neuroirudi tekniken aurrerakuntzek garunaren anatomia eta funtzionamendua aztertzeko aukerak zabaldu dituzte, irakurketan parte hartzen duten prozesuak zehatzago deskribatuz. Horrela bada, irakurtzen ikasteko heldutasun neurologikoan oinarritzen diren aurre-baldintza batzuk behar direla frogatu da zenbait ikerketatan (Flórez-Romero eta Arias-Velandia, 2009; Gallego, 2006; Scarborough, 2005). Aurre-baldintza horiek irakurketaren aurresaleak edo eragileak bezala kontsideratu daitezke etorkizuneko irakurketarekin korrelazioan daudelako (Romero, 2015).

Ildo horretatik, estatu mailan eginiko ikerketetan azpimarratzen diren irakurketaren aurrekariak edo aurresaleak zehazten dira ondorengo taulan (ikusi 1. taula):

1. taula

Irakurketaren eragileak eta aurresaleak ikerketa ezberdinen arabera

\begin{tabular}{|c|c|c|c|}
\hline Gallego (2006) & Cuetos (2014) & Suárez-Coalla (2013) & Defior (2014) \\
\hline $\begin{array}{l}\text { Irakurketa eragileak } \\
\text { Ezagutza fonologikoa } \\
\text { Ezagutza alfabetikoa } \\
\text { Izendatze abiadura } \\
\text { Irakurketa erraztai- } \\
\text { leak } \\
\text { Ahozkotasun maila } \\
\text { egokia } \\
\text { Maila kognitibo nahi- } \\
\text { koa } \\
\text { Lan-oroimena } \\
\text { Abilezia pertzeptibo } \\
\text { eta motorrak } \\
\text { Motibazio eta jokaera } \\
\text { alderdiak } \\
\text { Gizarte aldagaiak }\end{array}$ & $\begin{array}{l}\text { Segmentatze fonolo- } \\
\text { gikoa } \\
\text { Izendatze abiadura } \\
\text { arina } \\
\text { Aldagai linguistikoak } \\
\text { Aldagai kognitiboak }\end{array}$ & $\begin{array}{l}\text { Prozesatze fonologi- } \\
\text { koa (kontzientzia fo- } \\
\text { nemikoa, hitzezko } \\
\text { lan-oroimena, hitz- } \\
\text { jarioa) } \\
\text { Izendatze abiadura } \\
\text { arina }\end{array}$ & $\begin{array}{l}\text { Hautemate eta ikus } \\
\text { abileziak } \\
\text { Abilezia fonologikoak } \\
\text { Kontzientzia fonologi- } \\
\text { koko abileziak } \\
\text { Epe laburreko hitzezko } \\
\text { oroimena } \\
\text { Izendatze abiadura } \\
\text { arina } \\
\text { Automatizazio proze- } \\
\text { suak } \\
\text { Morfologia prozesuak } \\
\text { Prosodia }\end{array}$ \\
\hline
\end{tabular}

Ikus daitekeenez, irakurketa arrakastaren aurresaleez egindako ikerketetan aldagai ezberdinak zehazten diren arren, guztietan nabarmentzen 
da Kontzientzia fonologikoa eta Izendatze abiadura arina abilezien iragartzeko nagusitasuna. Ondorio hori nazioarte mailan eta beste hizkuntzetan eginiko ikerketekin bat dator (Share, 2008; Snowling, 2013). Beraz, berebiziko datua da, aldagai bi horien nagusitasuna hizkuntzaren ortografiaren independentziaz ematen dela. Hau da, bai hizkuntza ortografiko gardenetan (grafemen eta fonemen arteko korrespondentzia ematen den hizkuntzak; gaztelera, txekiera, eslovakiera, finlandiera) zein opakuetan (grafema bakoitzeko fonema anitzak egon daitezkeen hizkuntzak; ingelesa, holandera, frantsesa, hungariera) kontzientzia fonologikoa eta izendatze automatiko arina irakurketaren arrakasta iragartzeko aldagai indartsuenak direla frogatu da (Caravolas et al., 2012; Vaessen et al., 2010).

Euskararen kasuan, ez da irakurketaren aurresaleez eginiko ikerketarik aurkitu baina euskararen sistema ortografikoa gardena dela kontutan hartuz (grafema-fonema arteko erlazio eza kasu gutxitan gertatzen da, gehiengoetan fonema bakoitzari grafema bakarra dagokio) pentsa daiteke irakurketaren aurresale arrakastatsuenak kontzientzia fonologikoa eta izendatze automatiko arina ere izango direla, gazteleran edota finlandieran gertatzen den bezala. Hala ere, hori euskara batuaren kasuan izango litzateke eta bestelako gogoetak egin beharko lirateke gure euskalkien soinuen eta grafien arteko erlazioa aztertuz gero.

Irakurketaren garapenerako, kontzientzia fonologikoa eta izendatze abiadura arina abilezien garrantzia azpimarratu den arren, horiek «per se» ez dira gai irakurketaren arrakasta bermatzeko, ezta irakurketa zailtasunak iragartzeko ere. Horrela, ikerketa ezberdinek (Defior, 2014; Ziegler et al., 2010) irakurketaren garapenean eragiten duten aparteko abilezia eta prozesu kognitiboak identifikatu dituzte. Esku artean duzun lan honetan ikuspegi psikolinguistikotik egindako ikerketetako ondorioak bildu ondoren, hurrengoko lerroetan Haur Hezkuntzan landu beharko liratekeen abilezia kognitibo garrantzitsuenak deskribatzen dira.

\section{Prozesatze fonologikoa (kontzientzia fonologikoa eta oroimen fonologikoa)}

Prozesatze fonologikoak ahozko hizkuntza edo idatzizkoa prozesatzeko egiten dugun soinu edo fonologia-informazioaren erabilerari egiten dio erreferentzia (Torgesen eta Burgess, 1998). Melvi-Lervåg, Lyster eta Hulme (2012) autoreek bi motatako prozesatze fonologikoak bereizten dituzte: a) inplizitua, oroimen fonologikoa eta izendatze automatiko arina abileziak barne hartzen dituena eta b) esplizitua, kontzientzia fonologikoa barne hartzen duena.

Oroimen fonologikoa, iraupen laburreko oroimenean (ILO) informazio fonologikoa irudikatzeko abilezia da (Torgesen eta Burges, 1998). Oroimen hori funtsezkoa da prozesatze fonologikoan; ahozko elementuen sekuentzia bat gogoan edukitzeko, elementu horiek ezaugarri fonologikoen arabera irudikatu behar direlako iraupen laburreko oroimenean. 
Izendatze abiadura arinak irakurketaren garapenean duen eragina kontuan hartuta, aparteko puntu batean azalduko da.

Kontzientzia fonologikoak ahoskatutako hitz baten soinu-egituraz, edo egitura fonologikoaz, pertsona batek duen kontzientziari egiten dio erreferentzia (Gillon, 2007). Ahoskatutako hitzak atal txikiagotan bana daitezkeela ulertzea eskatzen du eta horretarako maila ezberdinetako abileziak barne hartzen ditu (Arnáiz, Castejón, Ruiz y Guiraola, 2002):

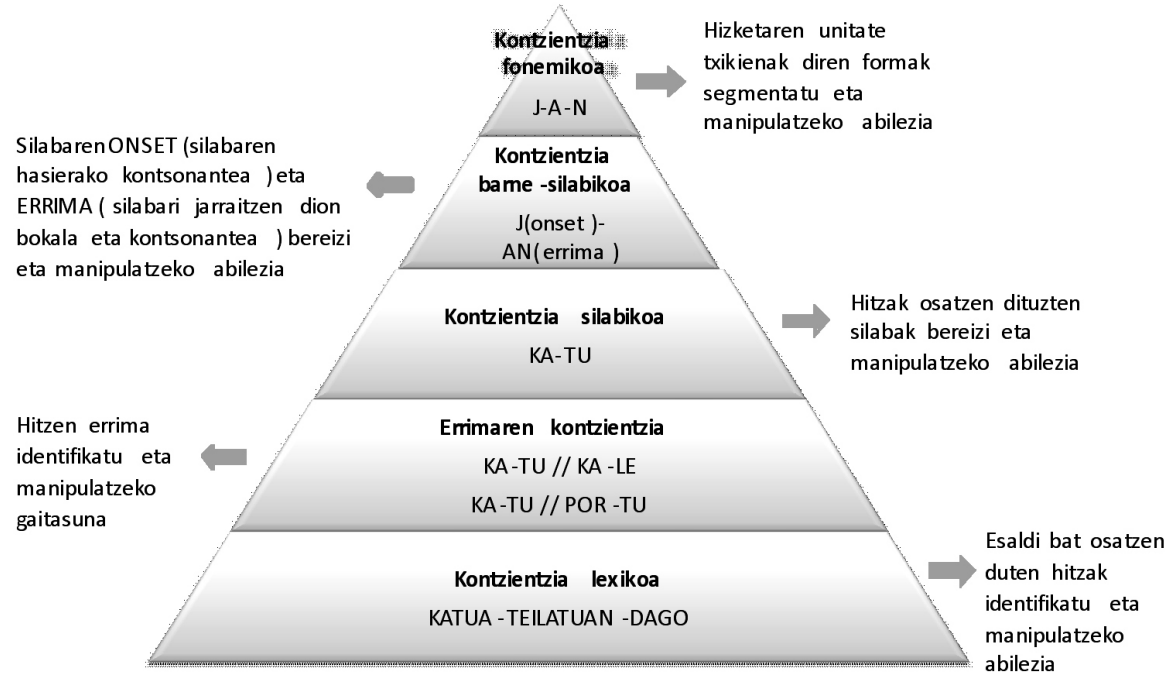

2. irudia

Kontzientzia fonologikoaren mailak

Kontzientzia fonologikoa (KF) irakurketaren arrakasta iragartzeko abilezia garrantzitsuena den arren, iragarpen balioa bere maila ezberdinen eta irakurketa-etapen arteko erlazioaren menpe dago. Horrela, KFaren lehen mailak irakurtzen ikasten hasteko aurretiko baldintzak dira, eta amaierako mailak irakurketarekin batera garatuko lirateke, irakurketaren ondorio bilakatuz (Hogan, Catts eta Little, 2005). Beraz, garrantzitsua da Haur Hezkuntzan KFren lehen mailak lantzea batez ere, (kontzientzia lexikoa, errima eta kontzientzia silabikoa) eta lehen hezkuntzan, irakurketarekin batera, KFren azken mailak.

\section{Izendatze abiadura arina}

Estimulu bisual ezagunak, hala nola, zenbakiak, koloreak, hizkiak eta objektuak, ahalik eta arinen izendatzeko gaitasunari deitzen zaio izendatze automatiko arina edo RAN (Rapid Automatized Named). Gaitasun horrek 
epe luzeko oroimenean ditugun errepresentazio fonologikoak arintasunez berreskuratzeko abileziak biltzen ditu. Abilezia horien bitartez, irakurtzerakoan hizki-kateen korrespondentzia fonologikoak arintasunez berreskuratzen dira, hizkien forma fonologikoa berehala lortuz. Horrela, izendatze abiadura arina irakurketa jariakortasunaren aurresale garrantzitsua bilakatzen da (Defior, 2014; Caravolas et al., 2012; Suárez-Coalla, García-deCastro eta Cuetos-Vega, 2013).

\section{Hizkien Ezagutza}

Hizkien ezagutzak hizkien izenak oroimenean irudikatzeko abilezia suposatzen du. Baina hizkiak identifikatzeko eta izendatzeko, haurrak mota ezberdinetako pertzepzio- eta ikus- abileziak garatuta izan behar ditu (Defior, 2014); hala nola, hizki eta hitzen ikus-pertzepzioaren zehaztasuna, hizkien formen ikus-analisia, antzekoak diren hizkien itxura ezberdintasuna $(\mathrm{b} / \mathrm{d}, \mathrm{m} / \mathrm{n}, \mathrm{f} / \mathrm{t} . .$.$) , hizki-patroien ikus-oroimena eta, begi-eskuen zein$ begi-espazioaren arteko trebetasunak. Hizkiak zuzen identifikatu eta izendatu ditzaketen haurrek errazago ikasiko dute soinuen eta grafien arteko korrespondentziak egiten (Adams, 1990). Hori dela eta, irakurketa garapen arrakastatsuarekin zuzenean erlazionatu den beste aldagaia da hau (Scarborough, 2002; Share, 2004).

\section{Ahozko hizkuntza}

Berninger, Abbott eta Thompson-ek (2002) esaten dutenez, lau hizkuntza sistemak (mintzamena, entzumena, irakurmena eta idazmena) modu gainjarrian eta paraleloan garatzen dira eta ez sekuentziazko faseetan. Hori dela eta, ahozko adierazpen eta ulermen zailtasunek irakurketa garatzean duten eragina ikertu da. Ahozko hizkuntza osatzen duten bost osagaietatik (fonologia, semantika, morfologia, sintaxia eta pragmatika), aipatu den bezala, alde fonologikoa da irakurketa garatzeko aldagai aurresale garrantzitsuena. Baina gainerako osagaiak ere erlazio zuzena dute hizkuntza idatziaren garatzearekin eta frogatua dago (Suárez-Coalla, García-de-Castro eta Cuetos-Vega; 2013) horien entrenamenduak eragin baikorra duela irakurketaren ikaskuntzan.

\section{Prosodia}

Prosodia hizkuntzaren osagai suprasegmentalak aztertzen dituen diziplina da; azentua, tonua, intonazioa, pausak, erritmoa, elokuzio-abiadura eta ahotsaren kalitatea (Romero, Etxebarria, Gaminde eta Garay, 2016). Gaitasun prosodikoa funtsezkoa da komunikazioa arrakastaz garatzeko. Horrela, lexikoa eta gramatika jabetzea erraztu egiten du (Morgan eta Demuth, 1996), eta irakurketa-idazketa garatzeko eragilea da (David, WadeWoolley, Kirby eta Smithrim, 2007). 
Beraz, abilezia eta prozesu horiek guztiak irakurketaren eragileak dira eta irakurketaren arrakasta iragartzeko informazioa ematen dute, beti ere garapen maila eta momentuaren arabera. Horrek irakurketa garatzeak duen konplexutasuna azpimarratzen du, haurrek mota ezberdinetako abileziak integratu behar dituztelako irakurtzen ikasteko eta horren automatismoa garatzeko, hau da, irakurketa egintza zehatza, arina eta ia inkontzientea bilakatzeko (Romero, 2015).

\section{IRAKURKETAREN ALDAGAI ERRAZTAILEAK GARATZEKO PROPOSAMENA}

Aurreko lerroetan deskribatutako irakurketa-ikaskuntzaren ikuspegi soziokulturalean eta linguistikoan oinarrituta, argi dago irakurtzen ikasi aurretik, haurrek abilezia eta ezagutza konkretu batzuk garatu behar dituztela. Atal honen helburua da, kode idatzia garatu baino lehen, haurrak garatu behar dituen prozesuak, abileziak eta jarrerak lantzeko proposamen integratzaile bat zehaztea. Horretarako, proposatzen diren jarduerak Haur Hezkuntzako geletara bideratzen dira eta bi alderdi ezberdinetan banatu dira:

a) Eskolaren eta haurraren arteko interakzioan oinarritutako jarduerak, esperientzia baikorrak sustatzeko eta irakurketaren gaineko interesa pizteko.

b) Irakurketaren arrakastarekin erlazionatzen diren abilezia eragileak garatzeko jarduerak, batez ere linguistikoak eta metalinguistikoak.

Hala ere, praktikan bi alderdietako jarduerak batera egitea komeni da, gelan lantzen den proiektuan integratuz.

\section{Irakurketaren aldeko harremana sustatzeko ekintzak eta jarduerak}

Haurra kode idatzia garatu baino lehen, bestelako prozesu garrantzitsu batzuk bereganatu behar ditu (Clemente, Rodríguez, Ramírez eta Martín-Domínguez, 2016); hala nola, irakurketaren funtzioaz jabetzea, jarrera baikorrak sentiaraztea, motibatzea eta irakurle izateko itxaropenak sortzea. Horretarako, umea testu idatziarekin kontaktuan egon behar da; alde batetik, idazketaren bitartez gauzak kontatu daitezkeela jabetu dadin, eta bestetik, irakurketa interesgarria, baliagarria eta dibertigarria izan daitekeela uler dezan. Modurik egokiena istorioak edo ipuinak entzutea da. Ipuinen narrazioaren bitartez, haurrek entzuten dutenaren esanahia eraikitzen doaz, baina baita erritmoa, idatzitakoaren egitura, mezu linguistikoa eta istorioaren edukia ulertzeko aukera dute (Clemente eta Rodriguez, 2014).

Baina ez du balio edozein ipuinek, edozein momentutan eta espaziotan. Pello Añorgaren esanetan $(2011 ; 25)$ «Haurtzaroan, ahotsa duen gorputza baita liburua», hori dela eta garrantzitsua da ahoz goran irakurtzeko 
prestatuak dauden ipuinak aukeratzea, eta halakoak espazio berean bildurik helduak zein haurrak kontatzea. Horrek, batetik, irakasleak ipuinak kontatzeko prestakuntza izan behar du, eta bestetik, ipuinak kontatzeko espazio eta momentu bereziak eraiki behar dira ikasgeletan.

Eusko Jaurlaritzak, ikastetxeek edo udalerrietako liburutegiek eskaintzen dituzten ikastaroez gain, badaude hainbat baliabide eskuragarri ipuinen kontaketaren teknikan trebatzeko. Hemen bi baliabide baino ez dira aurkeztuko. Bata, Bergarako Udalak (2010) ipuinak ondo kontatzeko argibideak, erremintak eta bestelako baliabideak biltzen dituen txostena. Bestea, Pello Añorgak (2012), «Aho bete hots» jardunaldietan emandako ipuinen testua, ahozko erregistroa, testuingurua, erritmoa, jarrera eta ahozko hizkuntzari buruzko irizpideak biltzen dituena.

Hala ere, kontuan hartu behar da ipuinez gain, beste hainbat testu mota ere badaudela eta komenigarria dela horiei hurbiltzea irakurketak betetzen dituen funtzioez jabetzeko. Adibidez, irakaslearekin batera sukalde liburuak erabiltzean, tarta bat egiteko osagaiak eta pausuak idatziz azaldu daitezkeela uler dezake; edota asteburuan herrian izandako gertaera garrantzitsu baten berri irakur dezakete egunkari digital batean. Hau da, beren intereseko gaiei buruzko informazioa liburuetan agertzen dela ulertu behar dute, horrela, irakurketak dituen funtzio ezberdinak ezagutuko dituztelako eta era berean irakurtzen ikasteko grina bultzatuko dugulako. Beraz, komenigarria da baliabide ezberdinak erabiltzea testu idatziak betetzen dituen funtzioak ikasteko; gaileta-paketeak dakarren testua, supermerkatuak bidalitako eskaintza berezien esku-orria, joko bateko erabilbideak eta abar. Beti ere, txoko eta une berezi bat utziz ipuinen kontaketa partekatuari.

Bestalde, liburuak eta testuak manipulatzen utzi behar dizkiegu, idatzizko lengoaiak hizkuntza irudikatzeko sistema dela ulertzeko eta bere berezitasunak behatzeko (Barone eta Mallette, 2013). Horretarako «haurtxoteka» izenez ezagutzen den liburutegi mota antolatu daiteke ikasgelan, haurrek gune eroso bat izan dezaten liburuak manipulatzeko, elkartrukatzeko edo informazioa biltzeko. Horrela liburu baten atalak identifikatu, irudi eta hitzak bereizi edota idatzitakoaren norabidea ezagutu dezakete.

Azkenik, irakurri osteko jarduerak ere burutu behar dira; ipuinen antzezpenak, irakurritakoaren sintesia, ulertu dutenari buruzko galderak eta abar. Jarduera horietan haurrek parte hartu behar dute, uler dezaten ezen errealitatea obejtuekin, lekuekin eta uneekin loturarik ez duten sinboloen bitartez interpreta daitekeela. (Clemente eta Rodriguez, 2014).

\section{Irakurketaren aurrekari psikolinguistikoak lantzeko ekintzak eta jarduerak}

Irakurketaren kodea bereganatzen eta automatizatzen ahal izateko haurrek aurretiazko trebetasun linguistiko eta metalinguistiko zehatz batzuk 
garatuta izan behar dituzte. Horrek irakurketa arrakastaz menperatzeko gaitzen ditu haurrak, baina, batez ere, hain konplexua den gaitasuna garatzeko bidea errazten die.

Ondorengo lerroetan, ikuspegi psikolinguistikotik teorikoki aztertu diren abilezia kognitibo garrantzitsuenak lantzeko proposamenak bideratzen dira. Batetik, abilezia bakoitza lantzeko jarduera zehatzak zehazten dira, lan espezifikoagoa egitea ahalbideratzen dutelako. Baina Haur Hezkuntzaren ikuspegi globalizatzailea eta parte-hartzailea lantzeko, proposamen zabalagoak ere adieraziko dira, geletan lantzeko aproposagoak direlako.

\section{Prozesatze fonologikoa}

Soinuen edo fonologia-informazioaren erabilera jorratzeko, proposatzen diren jarduerak bi motatako trebetasunak lantzean zuzentzen dira; oroimen fonologikoa eta kontzientzia fonologikoa.

Oroimen fonologikoa lantzeko, jarduerak hitz, zenbaki edo beste ahozko elementuen sekuentziak errepikatzean oinarritu behar dira, sekuentzien luzera handitzen joanik. Horrela, honako jarduera espezifiko hauek bideratu daitezke:

- Erlazionatuta ez dauden hitz zerrendak errepikatzea.

- Sasi-hitzak errepikatzea.

- Ordenatu gabeko eta errepikatzen ez diren zenbaki zerrendak errepikatzea.

- Esaldi bat entzun eta gero errepikatu.

Kontzientzia fonologikoa edo ahoskatutako hitz baten soinu-egitura lantzeko, maila ezberdinetako abileziak kontuan hartu behar dira. Maila bakoitza lantzeko jarduera zehatzak proposatzen dira ondoren (ikusi 3. irudia).

Hala ere, kontuan hartu behar da aurkeztutako jarduerak zailtasun maila ezberdina dutela. Hori dela eta, haurraren adina eta esperientzia ezinbesteko aldagai bilakatzen dira proposaturiko jarduerak aurrera eraman ahal izateko. 4-5 urteko haurren kasuan, kontzientzia lexikoa, errima eta kontzientzia silabikoa lantzea gomendatzen da; kontzientzia barne-silabikoa eta fonemikoaren garapena Haur Hezkuntzako 5-6 urteko gelarako eta Lehen Hezkuntzako lehen mailarako utziz.

Baliabide anitz topatu ditzakegu kontzientzia fonologikoa lantzeko, bai formatu inprimituan bai digitalean. Horietako bat Haranburu, Alonso, Balluerka eta Gorostiaga (2008) autoreek argitaratutako lana dugu; Kontzientzia fonologikoa lantzeko programa. Horretan kontzientzia fonologikoaren maila bakoitza garatzeko hainbat jarduera espezifiko proposatzen dira.

Baina jarduera espezifiko horiez gain, euskal kulturan baditugu prozesatze fonologikoa lantzeko bestelako baliabide paregabeak ere, besteak beste, kopla zaharrak, bertsoak, aho-korapiloak, herriko kantak, baladak 


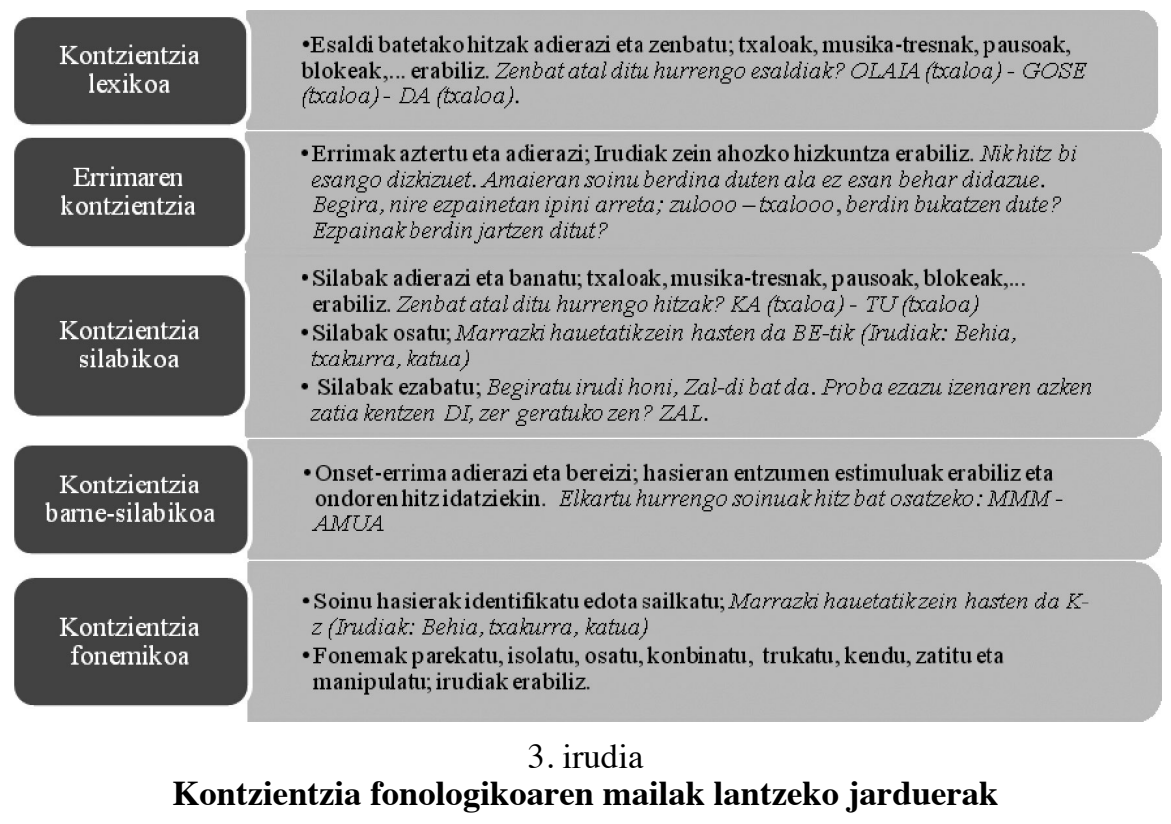

eta jolasketarako kantak (zotz egiteko, soka-saltoka, txalo-jokoak). Horien bitartez, oroimen zein kontzientzia fonologikoa landu daitezke ikasgelan, ikuspegi integratzaile eta ludiko batetik, tokian tokiko kultur ondarea bultzatzearekin batera.

\section{Izendatze abiadura arina}

Orokorrean, izendatze abiadura arina lantzeko jarduerak oinarritzen dira izenak eta zenbakiak ahalik eta azkarren izendatzean. Baina Haur Hezkuntzako haurrek ez dituzte hizkiak eta zenbakiak ezagutu behar, hori dela eta, izendatze abiadura arina abilezia entrenatzeko eta neurtzeko ikus estimuluak erabiltzen dira (ikusi 4. irudia). Horrela, orri batean irudikatutako marrazkiak ahalik eta arinen izendatzeko eska dakieke eta marrazkiak gehitu ahala denbora mugatu beren ezagutza maila handitzean. Garrantzitsua da hiztegi ezaguna erabiltzea, duten lexikoa arintasunez berreskuratzea delako helburua. 


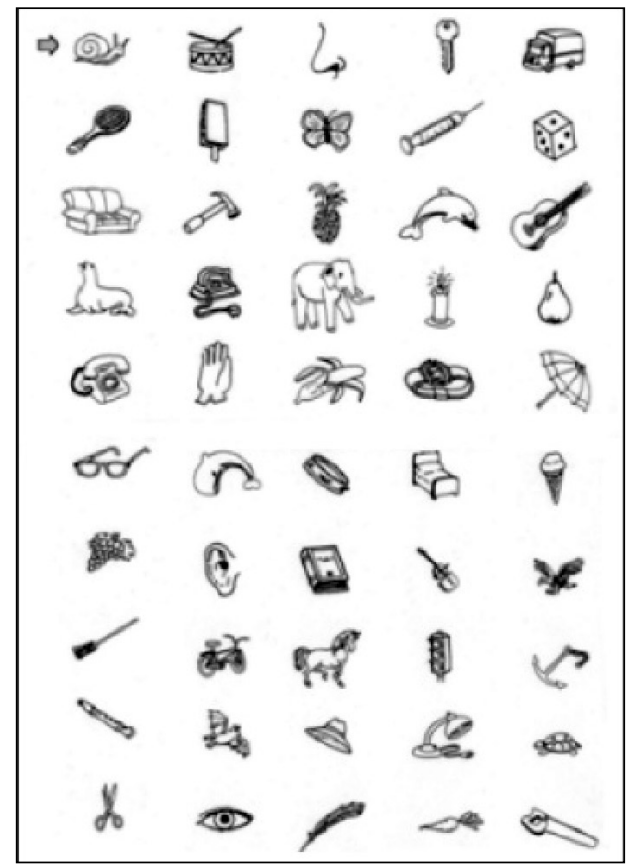

Iturria: Gómez-Velázquez, F.R. et al. (2010). La velocidad de denominación de letras: el mejor predictor temprano del desarrollo lector en español.

4. irudia

Izendatze automatiko arina lantzeko eredua

\section{Ezagutza alfabetikoa}

Hizkien ezagutza esplizitua izan dadin, hizkiak forma ezberdinetan eskain diezazkiekegu haurrei (magnetikoak, elkartzekoak, moldeak...), eredu batekin edo beren kabuz esploratzen joateko. Ohikoak diren baliabideak ere aproposak dira alfabetoa ikasteko; hizkia izen batekin erlazionatzea (E-elefantea) edota hizkia- bere formaren irudi batekin erlazionatzea (M-mendia).

Baina horretaz gain, garrantzitsua da haurrak hizkuntza idatziarekin kontaktuan egotea gelan, gelatik kanpo dauden bezala. Hau da, kaleetatik dauden errotuluak, horma-irudiak, bandoak, ordutegiak eta abar geletara ekarri behar ditugu. Sarritan Haur Hezkuntzako geletan txokoen izenak, haurren izenak edo beste izen solte batzuk baino ez dira azaltzen baina, egokia den arren, horrek ez du errealitatea irudikatzen. Adibidez, letrez jositako iragarkiak jarri ditzakegu eta azaldu zer esaten duen; edo txokoaren izenaren azpian, txoko horretan aritzeko ildoen zerrenda; edo haur bakoi- 
tzaren izenaren azpian, bere urtebetetze eguna eta gustuko dituen ekintzak. Horrekin, irakurketaren funtzioaz hausnartuko dute, idazteko eredu ezberdinak arakatuko dituzte eta, testuaren egitura eta puntuazio-markaz ohartuko dira, hizkiak ezagutzen dituzten heinean.

\section{Ahozko hizkuntza}

Gai oso zabala izanik, artikulu honetan irakurketaren garapenarekin harreman zuzena duten orientabideak eman dira. Hala ere, ahozko hizkuntzak Haur Hezkuntzan betetzen duen paper garrantzitsua azpimarratu nahi da. Haren bitartez haurrak bere pentsamendua, nortasuna, giza abileziak eta izaera eraikitzen ditu eta nahiak eta emozioak adierazten ditu. Beraz, dagokion arreta eman behar zaio Haur Hezkuntzan zein hezkuntzaren gainontzeko etapetan.

Baina aurkezten den lan honen harian, ahozko hizkuntza idazketaren aurrekari gisa bultzatzeko, ahozkoaren ulermena (nahita entzutea eta ulermenarekin erantzutea), ahozko adierazpena (lengoaia komunikatzeko erabiltzea) eta hiztegia jorratu dira batez ere (Barone eta Malette, 2013).

Ahozkoaren ulermena eta ahozko adierazpena lantzeko, irakasleek haurrekin elkarrizketak izateko tarteak bilatu behar dituzte ikasgelan, baita egoerak prestatu haurren arteko elkarrizketak bideratu daitezen. Lehendabizi, nahitaezkoa da irakasleek erabiltzen duten hizkuntzaz hausnartzea, eta erabiltzen dutena helburu zehatzekin egitea. Frogatuta dago irakaslearen hizkuntza haurren jokaerak zuzentzera eta gidatzera bideratzen denean, haurren hizkuntzaren ekoizpen kantitatean eragiten duela (Girolametto, Weitzman, Van Lieshout eta Duff, 2000). Bigarrenik, irakasleek hizkuntza garatua erabili behar dute, artikuluak, adjektiboak, preposizio-esaldiak, ideia ezberdinak biltzen dituzten esaldiak eta abar. Horrek guztiak haurren hizkuntza aberasten du.

Hiztegiaren garapenari dagokionez, kategoria bi bereizi daitezke; (1) haurrak adieraz dezakeen hitz kantitatea eta barietatea, (2) haurrak uler dezakeen hiztegia. Hiztegia garatzeko aurrera eraman daitezkeen jardueren artean, hitzen definizioak edo adibideak esplizituki emateak eta hiztegiari buruz eztabaidatzeak, haurren hiztegia aberasten du (Marulis eta Neuman, 2010). Bestalde, irakasleak hiztegi zabala erabili beharko luke eta esaldi berean sinonimoak erabili haurren hiztegia zabaltzeko. Hiztegia lantzeko beste jarduera espezifikoak honako hauek izango lirateke; familia semantikoak antolatzea, kontzeptuak analizatzea, kontrakoak bilatzea edo deskribapen txikiak egitea.

Ez ditugu ahaztu behar ere, herriko errefrauek eta esamoldeak hiztegia lantzeko aukera paregabea eskaintzen dutela, hala nola igarkizunek ere. 


\section{Prosodia}

Prosodia garatzeko jarduera espezifikoak intonazioa, etenak eta azentuak lantzean sailkatu dira. Intonazioaren kasuan, hiztunak duen intentzioaren arabera, perpausa mota ezberdinen (adierazpen, galde, harridura eta aginte perpausak) melodiak aztertu daitezke. Etenaldiei dagokienez, puntuazio-marken ahozko korrespondentziak lantzea izango da helburua. Horretarako, etenaldia egiten den tokiaren arabera, horrek hitzen esanahia nola aldatzen duen aztertu dezakete. Azkenik, azentuak lantzeko silaba eta hitz- tonikoen kokapenak, hitz baten edo esaldi baten esanahia nola aldatzen duen behatu dezakete.

Bestalde, Romero, Etxebarria, Gamindez eta Garay (2016) autoreen lanean ere proposamen didaktiko espezifikoa aurki daiteke prosodia lantzeko.

\section{ONDORIOAK}

Irakurtzeko gaitasuna da testu idatziak ulertzeko, erabiltzeko, berari buruzko gogoeta egiteko eta haiekin konprometitzeko duen gaitasuna (OECD, 2009b). Horrek haurrekin ezagutzak, jarrerak eta estrategiak garatzea dakar. Egun dugun hezkuntza markoak, irakurtzeko gaitasunaren garapena Haur Hezkuntzan, irakurketaren aldeko jarrera jorratzean eta irakurketaren dekodetzearen lehen hurbilketa burutzean oinarritzen du modu orokorrean. Bide horretan ez dira kontuan hartzen ikuspegi psikolinguistikotik eta soziokulturaletik egin diren ekarpen ugariak. Hori dela eta, kontuan hartu behar da irakurketa prozesuaren garapena, haur bati ipuin edo narrazio bat afektuzko testuinguru batean kontatzen diogunean hasten dela (Wolf, 2008). Hori dela eta, Haur Hezkuntzako geletan irakurketan parte hartzeko aukerak zabaldu eta testuingurua prestatu behar dugu irakurketa egintza sozialetik eraikitzeko.

Horretaz gain, literatura zientifiko zabala dago, haurraren aldez aurreko trebetasun eta ezagutza kognitibo zein psikolinguistiko konkretuak hizkuntza idatziaren garapenarekin erlazionatzen dituztenak (Defior, 2014; Ziegler et al., 2010). Horrela, prozesatze fonologikoa, izendatze abiadura arina, kontzientzia alfabetikoa, ahozko hizkuntza eta prosodia abileziek haurra prestatzen dute irakurketaren kode idatzia garatzeko. Horietatik, prozesatze fonologikoa eta izendatze abiadura arina azaltzen dira irakurketa-arrakastaren aurresale indartsuenak bezala (Suarez-Coalla et al., 2013). Beraz, Haur Hezkuntzako geletan trebetasun horiek lantzeak, haurra prestatzen du irakurketaren ikaskuntzari aurre egiteko. Bestalde, zailtasunak dituzten haurrak detektatzeko aukera ematen du, prebentziozko esku-hartzea abian jartzea posible eginez.

Horretarako guztirako, lan honetan proposamen integratzaile bat bideratzeko irizpideak deskribatu dira. Proposatzen diren jarduerak Haur Hez- 
kuntzako ikasgeletara bideratzen dira eta helburu bikoitza dute: (1) eskolaren eta haurraren arteko interakzioan oinarrituta, esperientzia baikorrak sustatu eta irakurketaren gaineko interesa piztu, (2) irakurketaren arrakastarekin erlazionatzen diren abilezia eragileak garatu.

Azkenik, artikulu honetan jarduera espezifikoak zehazten diren arren, gure tradizioak eskura jartzen gaituen eta ahaztuta ditugun hainbat baliabide azpimarratu nahi dira, hala nola, herri-ipuinak eta kondairak, bertsoak, kopla-zaharrak, esaerak, aho-korapiloak, asmakizunak, kantak eta ohiko jolasak (ikusi-makusi, sokasaltoa, txalo-jokoak). Horien bitartez, ikuspegi psikolinguistikotik eta soziokulturaletik eginiko ekarpenak aintzat hartzen ditugu, euskal kultura sustatuz. Ondorioz, lehen etxean eta kalean egiten ziren ume-jolasak eta tradizioak berreskuratu behar dira eta familia girora ez ezik, eskolara eramatea ere bide interesgarria da, testuinguru honek eskaintzen dituen aukera ugariez baliatzeko.

\begin{abstract}
Reading competence means decoding, understanding, using, reflecting and engaging with a written text. This does not begin with the formal learning of the written system, but it begins with the act of telling a story in childhood. This article carries out a theoretical study of the skills, processes and attitudes that are necessary to develop reading competence in Child Education, from the social-cultural and psycholinguistic approaches. Thus, the strategies necessary to make reading a social act are analyzed theoretically and psycholinguistic skills that are predictive and promoters of reading are determined. Finally, based on the contributions of the two theoretical currents, different proposals are presented to promote positive experiences and stimulate interest in reading, and to develop the precursory skills of reading success.
\end{abstract}

Keywords: Preschool, reading readiness, reading competence, skills development, teaching practice.

La competencia lectora supone decodificar, comprender, utilizar, reflexionar y comprometerse con un texto escrito. Esto no inicia con el aprendizaje formal del sistema escrito, sino que comienza con el acto de contar un cuento en la infancia. En este artículo se realiza un es- 
tudio teórico de las habilidades, procesos y actitudes necesarias para desarrollar la competencia lectora en Educación Infantil, desde los enfoques sociocultural y psicolingüístico. Así, se analizan teóricamente las estrategias necesarias para realizar de la lectura un acto social y se determinan las habilidades psicolingüísticas que son predictoras y promotoras de la lectura. Por último, tomando como referencia las aportaciones de las dos corrientes teóricas, se presentan diferentes propuestas para promover experiencias positivas y suscitar interés hacia la lectura, y para desarrollar las habilidades precursoras del éxito lector.

Palabras clave: Educación Infantil, preparación para la lectura, competencia lectora, desarrollo de las habilidades, práctica pedagógica.

La compétence en lecture suppose décoder, comprendre, utiliser, réfléchir et s'impliquer avec un texte écrit. Le point de départ n'est pas l'apprentissage formel du système écrit, mais cela commence avec l'acte de raconter une histoire dès la petite enfance. Dans cet article on réalise une étude théorique des aptitudes, des processus et des attitudes nécessaires pour développer la compétence en lecture dans l'Education Infantile, depuis les approches socioculturelle et psycholinguistique. Ainsi, on y analyse théoriquement les stratégies nécessaires pour faire de la lecture un acte social et on y détermine les aptitudes psycholinguistiques qui sont prédictives et promotrices de la lecture. Enfin, en prenant comme référence les apports des deux courants théoriques, on présente différentes propositions pour promouvoir les expériences positives et susciter l'intérêt pour la lecture, et pour développer les aptitudes précurseurs du succès de la lecture.

Mots-clé : Education Infantile, préparation pour la lecture, compétence en lecture, développement des aptitudes, méthode pédagogique.

\section{ERREFERENTZIAK}

Adams, M.J. (1990). Beginning to read: Thinking and learning about print. Cambridge, MA: MIT Press.

Alegria, J. (2006). Por un enfoque psicolingüístico del aprendizaje de la lectura y sus dificultades -20 años después - . Infancia y aprendizaje, 29 (1), 93-111.

Añorga, P. (2011). Haur-literatura eta ahozkotasuna. Behinola, 21-28.

Añorga, P. (2012). Kontalarien jarrera eta hizkuntz egokitzapena. Ahoa bete hots, 6, 43-57. 2017ko martxoaren 19an lortua hemendik: http://www.mintzola.eus/ 
eu/files/ahozko-elkargunea/ahoa-bete-hots-artikuluak/2012-ahoa-bete-hots-6kontalarien-jarrera-eta-hizkuntz-egokitzapena-pello-anorga.pdf/view

Arnáiz, P., Castejón, J.L., Ruiz, M.S., eta Guirao, J.M. (2002). Desarrollo de un programa de habilidades fonológicas y su implicación en el acceso inicial a la lecto-escritura en alumnos de segundo ciclo de educación infantil. Educación, desarrollo y diversidad, 5, 29-51.

Barone, D.M., eta Mallette, M.H. (Ed.) (2013). Best practices in early literacy instruction. Guilford Publications.

Beltrán J., López-Escribano, C., eta Rodríguez E. (2006). Precursores tempranos de la lectura: Educación Infantil y primer curso de Primaria. Gallardo, B., Hernández, C. eta Moreno, V. (Ed.), Lingüística clínica y neuropsicología cognitiva. Actas del primer congreso nacional de lingüística clínica. Valentzia: Lingüística y Evaluación del Lenguaje.

Bergarako Udala (2010). Ipuinak kontatzeko gida. 2017ko martxoaren 19an lortua hemendik: http://www.bergarakoeuskara.net/node/221406

Berninger, V., Abbott, R., eta Thompson, J. (2001). Language phenotype for reading and writing disability: A family approach. Scientific studies of reading, 5, 59-106.

Berritzegune Nagusia (2013). Hobekuntza plana: irakurtzeko gaitasuna. 2017ko urtarrilaren 12an lortua hemendik. http://nagusia.berritzeguneak.net/gaitasun/ docs/planesmejora/hobekuntzaplanadokhizk.pdf

Bruner, J. (1991): Actos de significado. Más allá de la revolución cognitiva. Madril: Alianza.

Caravolas, M., Lervåg, A., Mousikou, P., Efrim, C., Litavský, M., Onochie-Quintanilla, E., Salas, N., Defior, S., Mikulajová, M., Seidlová-Málková, G., eta Hulme, C. (2012). Common patterns of prediction of literacy development in different alphabetic orthographies. Psychological science, 23(6), 678-686.

Clemente, M., eta Rodriguez, I. (2014). Enseñanza inicial de la lengua escrita. De la teoría a la práctica. Aula, 20,105-121.

Clemente, M., Rodríguez, I., Ramírez, E., eta Martín-Domínguez, J. (2016). La narración en procesos de alfabetización inicial en un programa de biblioteca. Ocnos: Revista de estudios sobre lectura, 15(2), 50-66.

Cuetos, F. (2014). Psicología de la lectura. Madrid: Wolters Kluwer España.

David, D., Wade-Woolley, L., Kirby, J.R., eta Smithrim, K. (2007). Rhythm and reading development in school-age children: a longitudinal study. Journal of Research in Reading, 30(2), 169-183.

Defior, S. (2014). Procesos implicados en el reconocimiento de las palabras escritas. Aula, 20, 25-44.

Dehaene, S. (2009). Reading in the brain. The new science of how we read. New York: Penguin Group.

Flórez-Romero, R., eta Arias-Velandia, N. (2009). Evaluación de conocimientos previos del aprendizaje inicial de la lectura. Magis, Revista Internacional de Investigación en Educación, 2(4), 329-344.

Gallego, C. (2006). Los prerrequisitos lectores. Congreso Internacional de Lectoescritura. Morelia (México).

Gillon, G.T. (2007). Phonological awareness: From research to practice. Guilford Press. 
Gómez-Velázquez, F.R., González-Garrido, A.A., Zarabozo, D., eta Amano, M. (2010). La velocidad de denominación de letras: el mejor predictor temprano del desarrollo lector en español. Revista mexicana de investigación educativa, 15(46), 823-847.

Haranburu, M., Alonso, I., Balluerka, N., eta Gorostiaga, A. (2008). Kontzientzia fonologikoa lantzeko programa. Donostia: Erein.

Harris, J.L. (2003). Toward an understanding of literacy issues in multicultural school-age populations. Language, Speech, and Hearing Services in Schools, $34,80-82$.

Hogan, T.P., Catts, H.W., eta Little, T.D. (2005). The Relationship Between Phonological Awareness and ReadingImplications for the Assessment of Phonological Awareness. Language, Speech, and Hearing Services in Schools, 36(4), 285-293.

Jiménez, J., eta Artiles, C. (1990). Factores predictivos del éxito en el aprendizaje de la lectoescritura. Infancia y Aprendizaje, 49, 21-36.

Korat, O., Klein, P., eta Segal-Drori, O. (2007). Maternal mediation in book reading, home literacy environment, and children's emergent literacy: A comparison between two social groups. Reading and Writing, 20(4), 361-398.

Lonigan, C.J. (2004). Emergent literacy skills and family literacy. Handbook of family literacy, 57-82.

Marulis, L.M., eta Neuman, S.B. (2010). The effects of vocabulary intervention on young children's word learning: A meta-analysis. Review of educational research, 80(3), 300-335.

Melby-Lervåg, M., Lyster, S.A.H., eta Hulme, C. (2012). Phonological skills and their role in learning to read: a meta-analytic review. Psychological Bulletin, $138(2), 322-352$.

Morgan, J.L., eta Demuth, K. (ed.) (1996). Signal to Syntax: Boots traping From Speech to Grammar in Early Acquisition. New York: L. ErlbaumAssociates.

OECD (Ed.). (2009b). El programa PISA de la OCDE. Qué es y para qué sirve. Paris: OECD Publishing.

Reese, E., Cox, A., Harte, D., eta MCanally, H. (2003). Diversity in Adult s Styles of Reading Books to Children. A. Van Kleeck, S.A. Stahl eta E. B. Bauer (ed.) On Reading Books to Children. Parents and Teachers (pp. 37-57). Mahwah, NJ: Lawrence Erlbaum Associates.

Romero, A. (2015). Irakurketa zailtasunei aurrea hartzeko software didaktiko baten diseinua eta ebaluazioa. Doktoretza-tesia. UPV/EHU.

Romero, A., Etxebarria, A., Gaminde, I., eta Garay, U. (2016). El papel de la prosodia en la enseñanza de la L1. Un aporte didáctico para el aula de educación infantil y de educación primaria. Phonica, 11, 64-86.

Scarborough, H.S. (2002). Connecting early language and literacy to later reading (dis)abilities: Evidence, theory, and practice. En S.B. Neuman \& D.K. Dickinson (Eds.), Handbook of early literacy research, 97-110. New York: Guilford Press.

Scarborough, H.S. (2005). Developmental relationships between language and reading: Reconciling a beautiful hypothesis with some ugly facts. H.W. Catts, eta A.G. Kamhi (Eds.), The connections between language and reading disabilities, 3-24. Mahwah, NJ: LEA. 
Share, D.L. (2004). Knowing letter noums and learning letter sounds: A causal connection. Journal of Experimental Child Psychology, 88(3), 2013-233.

Share D. L. (2008). On the anglocentricities of current reading research and practice: The perils of overreliance on an «outlier» orthography. Psychological Bulletin, 134, 584-615.

Snow, C., Burns, M., eta Griffin, P. (1998). Preventing reading difficulties in young children. Washington, DC: National Academy Press.

Snowling, M.J. (2013). Early identification and interventions for dyslexia: a contemporary view. Journal of Research in Special Educational Needs, 13, 1, 7-14

Suárez-Coalla, P. eta Cuetos-Vega, F. (2012). ¿ Es la dislexia un trastorno perceptivo-visual? Nuevos datos empíricos. Psicothema, 24(2), 188-192.

Suárez-Coalla, P., García-de-Castro, M., eta Cuetos-Vega, F. (2013). Variables predictoras de la lectura y la escritura en castellano. Infancia y Aprendizaje, 36 (1), 77-89.

Sulzby, E., eta Teale, W. (1991). Emergent literacy. R. Barr, M.L. KamiL, P.B. Mosenthal eta P.D. Pearson (ed.) Handbook of Reading Research,. 727758. New York: Longman.

Teale, W.H. (1984). Reading to young children: Its significance for literacy development. H. Goelman, A. Oberg eta F. Smith (ed.), Awakening to literacy, 110121. Portsmouth, NH: Heinemann.

Torgesen, J.K., eta Burgess, S.R. (1998). Consistency of reading-related phonological processes throughout early childhood: Evidence from longitudinal-correlational and instructional studies. Word recognition in beginning literacy, 161-188.

Vaessen, A., Bertrand, D., Tóth, D., Csépe, V., Faisca, L., Reis, A., eta Blomert, L. (2010). Cognitive development of fluent word reading does not qualitatively differ between transparent and opaque orthographies. Journal of Educational Psychology, 102, 827-842.

Vygotsky, L. (1979): El desarrollo de los procesos psicológicos superiores. Barcelona: Crítica.

Wasik, B.H. (2012). Handbook of family literacy. NY: Routledge.

Wolf, M. (2008). Cómo aprendemos a leer. Bartzelona: Ediciones B.

Ziegler J.C., Bertrand D., Tóth D., Csépe V., Reis A., Faísca L., eta Blomert L. (2010). Orthographic depth and its impact on universal predictors of reading:

A cross-language investigation. Psychological Science, 21, 551-559. 